\title{
SOME STUDIES ON DIGENETIC TREMATODES OF HERRING GULL (LARUS ARGENTATUS) AT PORT SAID GOVERNORATE
}

\author{
SAMAR W. TADROS ${ }^{*}$ JIHAN F.K. ABO-ESA ${ }^{* *}$ and AMAL K. EL- GAYAR ${ }^{* * *}$ \\ *Animal Health Research Institute, Port Said branch, Parasitology Unit. \\ ** Animal Health Research Institute, Fish Disease Department, Fish Parasites Unit. \\ *** Suez Canal University, Faculty of Veterinary Medicine, Department of Parasitology
}

\section{ABSTRACT}

Received at: 17/6/2013

Accepted: 18/7/2013
During present study on the helminth parasites of herring gulls (Larus argentataus) in El Manzala Lake and Mediterranean Sea near Port Said city of Egypt, a total of 65 birds were infected with one or more species of intestinal digenetic trematodes, including 6 species, Petasiger grandevesicularis, Petasiger jubilarum, Petasiger skrjabini, Stephanoprora spinosa, Dolichosacculus solecarius and Tylodelphys sp. The morphometric features of each species were compared with earlier descriptions. The total prevalence of parasitic infestation in herring gulls was $61.54 \%$. The prevalence of isolated trematodes were: $P$. grandevesicularis 25,00 \%, P. jubilarum $9.23 \%$, P. skrjabini $7.69 \%$, S. spinosa $12.30 \%$, D. solecarius $7.69 \%$ and Tylodelphys sp. $9.23 \%$. The public health hazards of the isolated parasites were discussed.

Key words: Digenetic trematodes, Herring Gull, Prevalence, Egypt.

\section{INTRODUCTION}

Port Said is a city located $31^{\circ} 15^{\circ} \mathrm{N} 32^{\circ} 17^{\circ} \mathrm{E}$ that lies in north east Egypt extending about 30 kilometers along the coast of the Mediterranean Sea with magnificent lake and wetlands have always been regarded as welcoming grounds for the millions of many local and migratory aquatic birds during the winter. Wild birds play an important role in spreading diseases and parasites to domesticated birds and even to man (Soulsby, 1986). On the other hand, wild aquatic birds may transmit diseases to the fishes as these birds act as final hosts for many trematodes whose larvae infect fishes and cause diseases in them (Williams and Jones, 1994). Seagulls are birds in the family Laridae. They are most closely related to the terns (Family: Sternidae). Most gulls, particularly Larus species, are ground-nesting carnivores, which will take live food. Live food often includes crabs and fish, Grant (1986), Olsen and Larsson (1995) and Howell and Jon (2007). Although there are many reports have been published on helminths of various species of the gulls from many parts of the world (Torres et al., 1991; Uchida et al., 1991; Kostadinova, 1995; Eyda et al., 1996; Kreiter and Semenas, 1997; Roca et al., 1999) the literature on the helminth parasites of aquatic birds in Egypt is not sufficient (Abdel-Aal et al., 2001; Abdel-Aal and El-Sayed 2003; Ghattas, 2004). The world health organization (WHO), recorded the number of people currently infected with fish-borne trematodes exceed 18 million and the number of people at risk world wide estimated at more than half a billion (Thu et al., 2007).

The life cycle of trematodes differ from one species to another, but in general two intermediate hosts are required. The first intermediate host is snail, but second intermediate host may be another snail, a bivalve mollusk, a tadpole or a fish. The definitive host, including man in case of zoonotic trematodes, becomes infected by consuming raw foods (intermediate hosts) containing metacercariae (Pan American Health Organization, 2003).

Regarding this point of view the aims of this study were to determine the trematodes infecting gulls in Port Said City, to compare the species of trematodes infecting herring gulls with those studied earlier.

\section{MATERIALS and METHODS}

A total of 65 herring gull (Larus argentatus) (Charadriiformes: Laridae) collected from different shores of El-Manzala Lake, Mediterranean Sea at ElGameel district, Port Said City, Egypt were examined for digenetic trematodes during the period of January till May 2011. Trematodes were collected in $0.9 \%$ saline, fixed under slight cover glass pressure in alcohol formalin- acetic acid (AFA), stained with acetic acid alum carmine, dehydrated in a graded series of ethanol solutions (30-100\%) and cleared in clove oil and xylol. Specimens were finally mounted in Canada balsam. All measurements are given in 
millimeter $(\mathrm{mm})$ and eggs in micrometer $(\mu \mathrm{m})$ as described by Fahmy and Selim (1959). Specimens were identified and compared with the literature available.

\section{RESULTS}

Fourty herring gull (Larus argentatus) out of 65 $(61.5 \%)$ were infected with at least one intestinal trematode species (table 1). For each species a minimum of 10 specimens was examined and a description was developed.

Order: Digenea (Van Beneden, 1858)

Suborder: Prosostomata (Odhner, 1905)

Family: Echinostomatidae (Poche, 1926)

Subfamily: Echinostomatinae (Faust, 1929)

Genus: $\quad$ Petasiger (Dietz, 1909)

Species: Petasiger skrjabini (Baschkirova, 1941)

Petasiger jubilarum (El'perin, 1937)

Petasiger grandevesicularis (Ishii, 1935)

Stephanoprora spinosa (Odhner, 1911)

1-Petasiger skrjabini (Baschkirova, 1941) Echinostomatidae was obtained from the small intestine of 5 birds. P. skarjabini (Fig.1) have small body plump, broadly fusiform, with maximum breadth at middle; body $1.28-1.78 \mathrm{~mm}$ long; 0.34$0.37 \mathrm{~mm}$ wide. Neck region more or less constricted. Head collar reniform, large, with double, dorsally uninterrupted row of spines. Oral sucker subterminal and subspherical. Ventral sucker pre-equatorial, large with average length $0.15 \mathrm{~mm}$ and average width 0.28 mm. (width $61-87 \%$ of maximum body width). Prepharynx short; pharynx elongate oval; oesophagus long; intestinal bifurcation at $24-47 \%$ of body length, anterior to the margin of cirrus-sac; caeca end blindly halfway between posterior testis and posterior extremity. Caeca reach close to posterior extremity. Testes tandem, opposite, near posterior extremity. Cirrus pouch small and entirely pre-acetabular. Acetabulum average length is $0.35 \mathrm{~mm}$ and its average width is $0.31 \mathrm{~mm}$. Ovary round and submedian situated anterior to the left testes. Uterus short; eggs few, large 66-77 $\mu \mathrm{m}$ long and the number up to seven. Vitellaria lateral reaching forward beyond acetabulum till behind the testes. It is intestinal parasites of birds (Faltynkova et al., 2008).

2- Petasiger jubilarum (El'perin, 1937) (Fig. 2) Echinostomatidae was found in the small intestine of 6 birds (table 1). It has slender elongated body; 1.28 $\mathrm{mm}$ long and neck region less constricted. Head collar reniform, large and with double, dorsally uninterrupted row of spines. Cephalic collar spines were $27 ; 5$ spines in ventral lobes, 3 corner spines 53$67 \mu \mathrm{m}$ long and other spines 38- $54 \mu \mathrm{m}$ long. Esophagus was $400 \mu \mathrm{m}$ long. The fore body is extended; body elongate, fusiform, small (body length $<2,500 \mu \mathrm{m}$; body width $<500 \mu \mathrm{m}$ ), acetabulum postequatorial; ventral sucker pre-equatorial; testes oblique, tandem near posterior extremity; overlap and smaller than eggs. Cirrus pouch small and almost entirely pre-acetabular. Ovary round submedian and pretesticular. Uterus short; eggs few and large. Vitellaria extending in lateral fields of behind body postacetabular and reach to level of ventral sucker (Yamaguti, 1958 and McDonald, 1981).

3- Petasiger grandevesicularis (Ishii, 1935) (Fig. 3), Echinostomatidae was found in the small intestine of 10 birds. Body was small 0.6- $1.75 \mathrm{~mm} \times 0.27-0.45$ $\mathrm{mm}$, plump, broadly fusiform, with maximum breadth at middle and the neck region more or less constricted. Head collar was reniform, large, with 19 double spines, dorsally uninterrupted row of spines, angle spines 50-96 $\mu \mathrm{m}$ long. And other collar spines 24-66 $\mu \mathrm{m}$. Esophagus was short. Acetabulum equatorial may be postequatorial when the forebody is extended. Testes were tandem near posterior extremity. Cirrus pouch small, entirely preacetabular. Ovary was round, submedian. Uterus was short; eggs few and large. Vitellaria were lateral and extend as far forward as intestinal bifurcation (Yamaguti, 1939 and 1958; McDonald, 1981 and Faltynkova et al., 2008).

4- Stephanoprora spinosa (Odhner, 1911) (Fig. 4). Echinostomatidae, was found in the small intestine of 8 birds, body very much elongated, 2.9-3.6 mm long and $0.54-0.60 \mathrm{~mm}$ wide and spined anteriorly. Head collar reniform, with dorsally interrupted crown of spines. Pharynx longer than oral sucker which is $0.18-0.2 \mathrm{~mm}$ long and 0.34- $0.39 \mathrm{~mm}$ wide. Acetabulum in anterior third of body $0.34-0.39 \mathrm{~mm}$ long and o.32-0.35 mm wide. Testes was median, directly tandem and in middle third of body. Cirrus pouch small and anterior to acetabulum. Ovary was median and a little in front of anterior testis. Eggs were few, four to seven, 60- $88 \mu \mathrm{m}$ long. Vitellaria occupying entire post-testicular region not extend forward to testicular zone. Uterus not very long (Yamaguti, 1958 and McDonald, 1981).

Family: Cathaemasiidae (Fuhrmann, 1927)

Subfamily: Cathaemasiinae (Dollfus, 1950)

Genus: Dollichosacculus (Johnston, 1942)

Genotype: Dolichosacculus solecarius (Johnston, 1917)

5- Dolichosacculus solecarius (Johnston, 1917) (Fig. 5). Cathaemasiidae, Five herring gulls were infected by this trematode, as its larval stages isolated from the small intestine. The parasite was small, cylindrical, with mean length $1.08 \mathrm{~mm}$ and mean width $0.22 \mathrm{~mm}$; spinose body and oral sucker was subterminal and very large $(0.145$ and $0.160 \mathrm{~mm}$ mean length and width respectively). There were four lobed pharynx, esophagus partically absent and ceca 
opened terminally in posterior end. Acetabulum smaller than oral sucker which is rounded with average diameter $0.045 \mathrm{~mm}$, in anterior half of the body and the testes were entire, directly tandem in posterior third of body. Ovary between acetabulum and anterior testes. Uterus winding between postovarian shell gland and genital gland. Vitellaria confined fields of hindbody (Yamaguti, 1958).

Family: Diplostomatidae (Poirier, 1886)

Subfamily: Diplostomatinae (Monticelli, 1892)

Genus: Tylodelphys (Diesing, 1850)

Genotype: Tylodelphys sp. (Nordmann, 1832)

6- Tylodelphys sp. (Nordmann, 1832), (Fig. 6). Diplostomatidae, Six herring gulls were infected by this trematode. It has pseudosuckers. Body barely, two segmented; with average length $1.69 \mathrm{~mm}$ and average width $0.62 \mathrm{~mm}$. Anterior extremity indistinctly trilobate. Oral sucker length is 0.14- 0.16 $\mathrm{mm}$ and its width is $0.15-0.17 \mathrm{~mm}$. Tribocytic organ rounded, one-third to one-sixth as long as forebody, with its cavity opening by median slit. Hind body was conical and in direct continuation of forebody. Testes symmetrical, curved in form of horse-shoe, with ventral concavity and the anterior one was larger than posterior. Ovary was submedian and pretesticular. Vitellaria extending beyond acetabulum. The mean length and width of acetabulum are $0.125 \mathrm{~mm}$ and $0.135 \mathrm{~mm}$ respectively. Bursa with subterminal pore and genital cone is small, with opening of hermaphroditic canal at its tip (Yamaguti, 1958).

Table 1: Prevalence of Trematodes infestation in herring gulls (larus argentatus)

\begin{tabular}{clcc}
\hline No. of examined birds & \multicolumn{1}{c}{ Isolated parasites } & $\begin{array}{c}\text { No. of infected } \\
\text { birds }\end{array}$ & Prevalence (\%) \\
\hline & $\begin{array}{c}\text { 1-Petasiger skrjabini } \\
\text { 2-Petasiger jubilarum }\end{array}$ & 5 & 7.69 \\
3- Petasiger grandevesicularis & 6 & 9.23 \\
& 4-Stephanoprora spinosa & 10 & 25.00 \\
& 5- Dolichosacculus solecarius & 8 & 12.30 \\
& 6- Tylodelphys sp. & 5 & 7.69 \\
& & 6 & 9.23 \\
\hline 65 & & 40 & $61.54 \%$ \\
\hline
\end{tabular}

Table (2): Comparison between four Echinostomatidae species isolated from herring gull:

\begin{tabular}{|c|c|c|c|c|c|c|c|c|c|}
\hline $\begin{array}{l}\text { 1-Petasiger } \\
\text { skrjabini }\end{array}$ & $1.28-1.78$ & $0.34-0.37$ & $\begin{array}{l}\text { Subter- } \\
\text { minal }\end{array}$ & long & $\begin{array}{c}0.15 \mathrm{~mm} \\
\text { long- } 0.28 \\
\text { mm wide }\end{array}$ & Present & $\begin{array}{c}\text { Submedian } \\
\text { Anterior to } \\
\text { left testis }\end{array}$ & $\begin{array}{l}\text { near post- } \\
\text { erior end }\end{array}$ & $\begin{array}{l}\text { lateral, beyond } \\
\text { acetabulum till } \\
\text { behind } \\
\text { the testes }\end{array}$ \\
\hline $\begin{array}{c}\text { 2-Petasiger } \\
\text { jubilarum }\end{array}$ & 1.28 & - & $\begin{array}{l}\text { Subter- } \\
\text { minal }\end{array}$ & $\begin{array}{l}400 \mu \mathrm{m} \\
\text { long }\end{array}$ & $\begin{array}{l}\text { pre- } \\
\text { equatorial }\end{array}$ & $\begin{array}{c}\text { post } \\
\text { equatorial }\end{array}$ & $\begin{array}{l}\text { submedian and } \\
\text { pretesticular }\end{array}$ & $\begin{array}{c}\text { near } \\
\text { posterior end }\end{array}$ & $\begin{array}{l}\text { lateral fields of } \\
\text { behind body, } \\
\text { postacetabula, } \\
\text { to level of } \\
\text { ventral sucker }\end{array}$ \\
\hline $\begin{array}{l}\text { 3- Petasiger } \\
\text { grandevesicularis }\end{array}$ & $0.6-1.75$ & $0.27-0.45$ & $\begin{array}{c}\text { Subter- } \\
\text { minal }\end{array}$ & Short & - & equatorial & submedian & $\begin{array}{c}\text { near } \\
\text { posterior end }\end{array}$ & $\begin{array}{l}\text { lateral, extend } \\
\text { as far forward } \\
\text { as intestinal } \\
\text { bifurcation }\end{array}$ \\
\hline $\begin{array}{l}\text {-Stephanoprora } \\
\text { spinosa }\end{array}$ & $2.9-3.6$ & $0.54-0.60$ & $\begin{array}{l}\text { Subter- } \\
\text { minal }\end{array}$ & $\begin{array}{l}\text { very much } \\
\text { elongated }\end{array}$ & - & $\begin{array}{c}\text { in anterior } \\
\text { third of } \\
\text { body }\end{array}$ & $\begin{array}{l}\text { median, in front } \\
\text { of anterior testis }\end{array}$ & $\begin{array}{l}\text { in middle } \\
\text { third of body }\end{array}$ & $\begin{array}{l}\text { entire post- } \\
\text { testicular } \\
\text { region }\end{array}$ \\
\hline
\end{tabular}




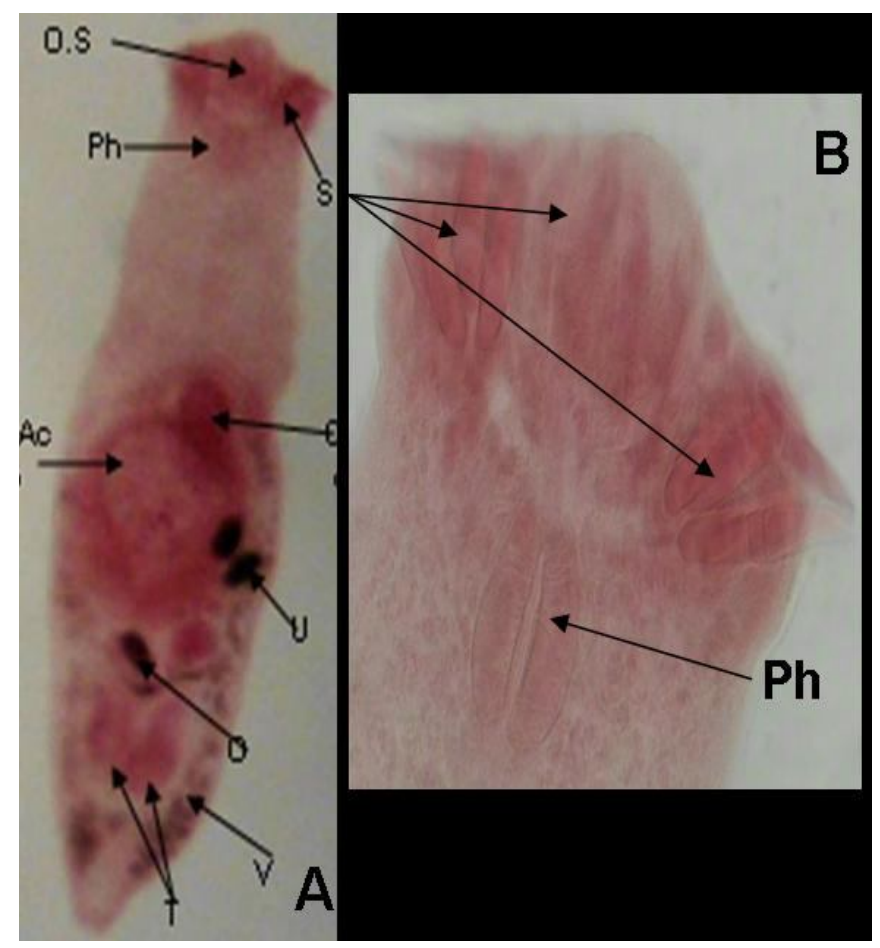

Fig. (1): Petasiger skrjabini. A) The whole worm, B) Anterior end. $\mathrm{O} . \mathrm{S}=$ Oral sucker, $\mathrm{S}=\mathrm{Spine}, \mathrm{Ph}=$ pharynx, $\mathrm{C}=$ Cirrus pouch, $\mathrm{Ac}=$ Acetabulum, $\mathrm{U}=$ Uterus with eggs, $\mathrm{O}=$ Ovary with eggs, $\mathrm{V}=$ Vitellaria, $\mathrm{T}=$ Two testes.

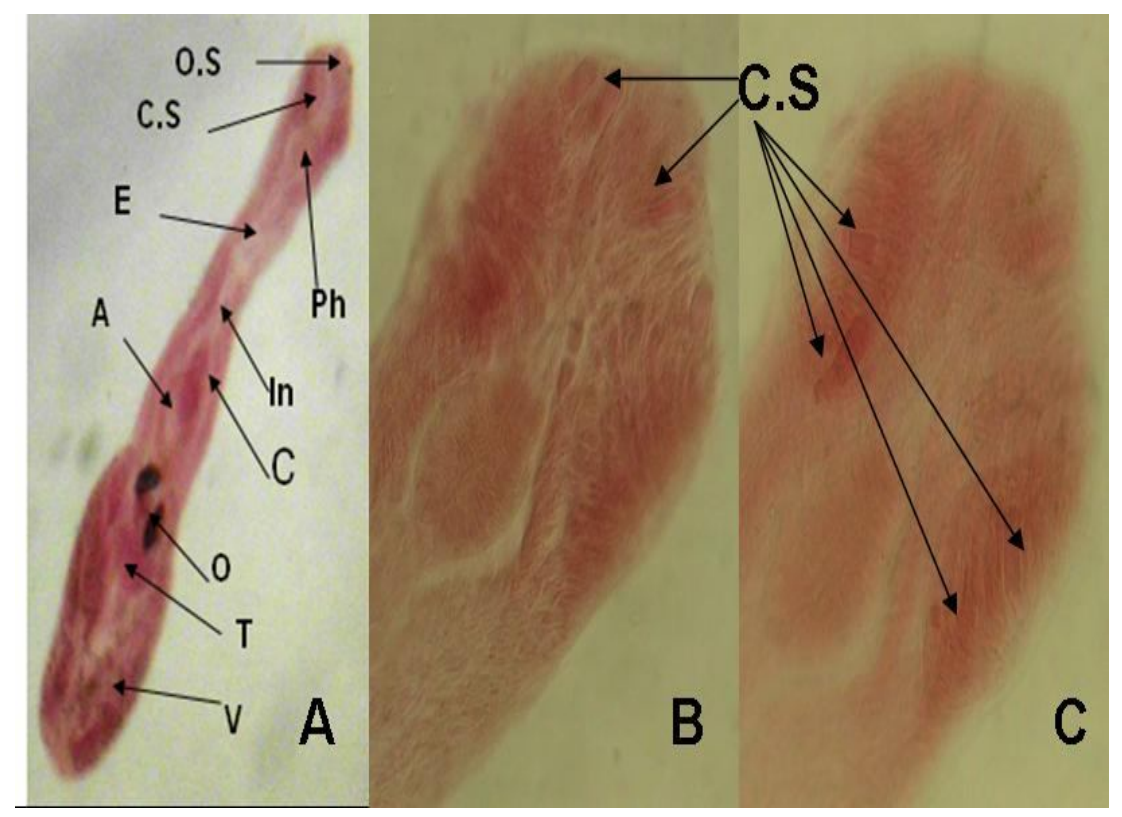

Fig. (2): Petasiger jubilarum. A) The whole worm. B \&C) Anterior End. O.S = Oral sucker, C.S=Corner spines, $\mathrm{Ph}=$ Pharynx, $\mathrm{E}=$ Esophagus, In= Intestinal bifurcation, $\mathrm{C}=$ Cirrus pouch, $\mathrm{O}=$ ovary with eggs, $\mathrm{T}=$ Two testes, $\mathrm{V}=$ Vitellaria. 


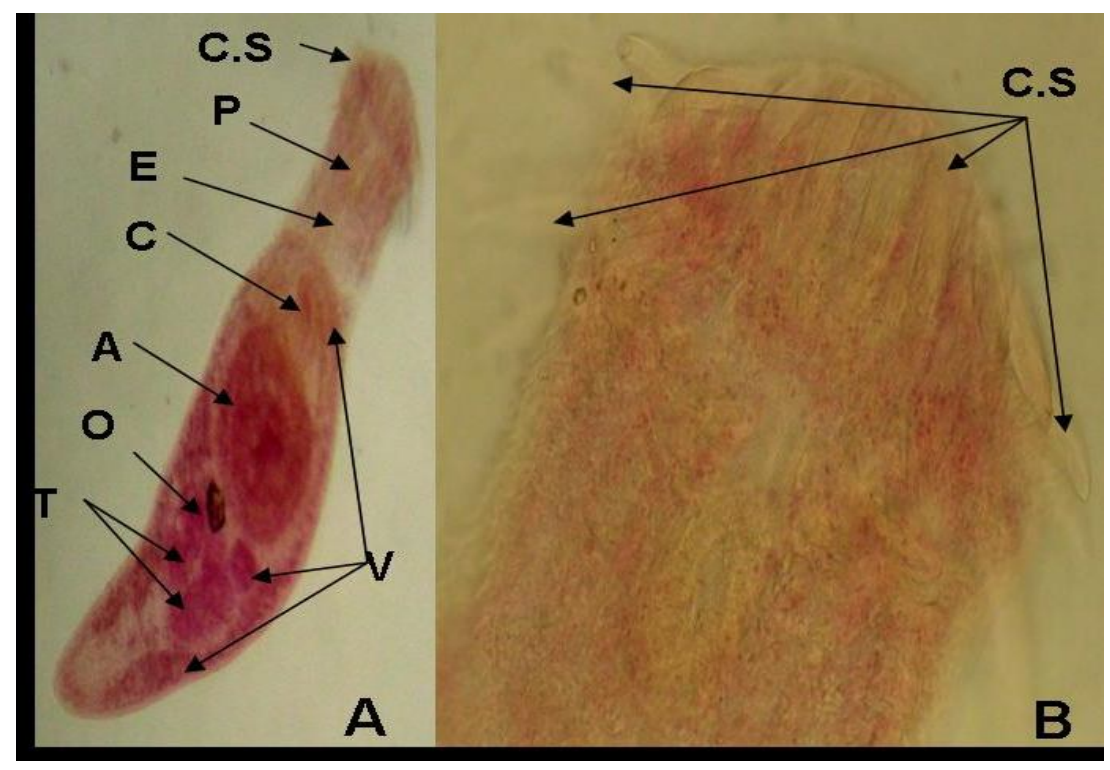

Fig. (3): Petasiger grandevesicularis. $\mathrm{C} . \mathrm{S}=$ Crown of spines, $\mathrm{P}=$ Pharynx, $\mathrm{E}=$ Esophagus, $\mathrm{C}=$ Cirrus pouch, $\mathrm{A}=$ Acetabulum, $\mathrm{O}=$ Ovary, $\mathrm{T}=$ Two testes, $\mathrm{V}=$ Vitellaria.

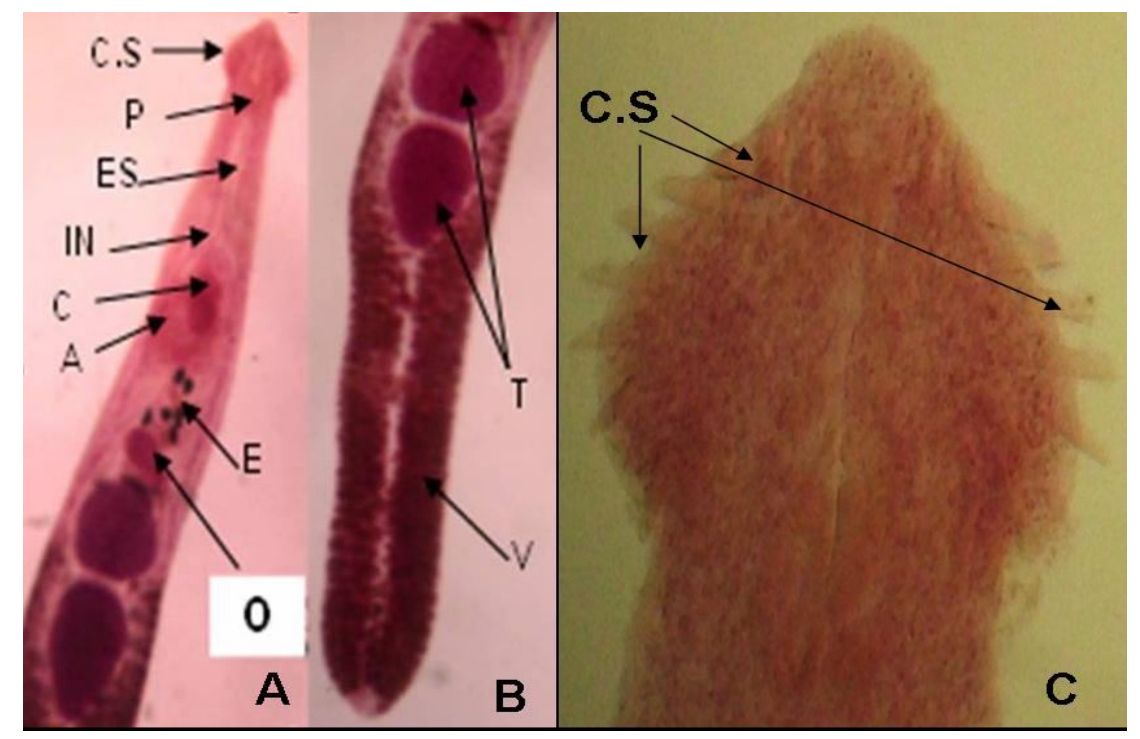

Fig. (4): Stephanoprora spinosa. A) Anterior end. B) Posterior end. C) Oral sucker with crown of spines. C.S= Crown of spines, $\mathrm{P}=$ Pharynx, $\mathrm{ES}=$ Esophagus, $\mathrm{IN}=$ Intestinal bifurcation, $\mathrm{C}=$ Cirrus pouch, $\mathrm{A}=$ Acetabulum, $\mathrm{E}=$ Eggs, $\mathrm{O}=$ Ovary, $\mathrm{T}=$ Two testes, $\mathrm{V}=$ Vitellaria. 


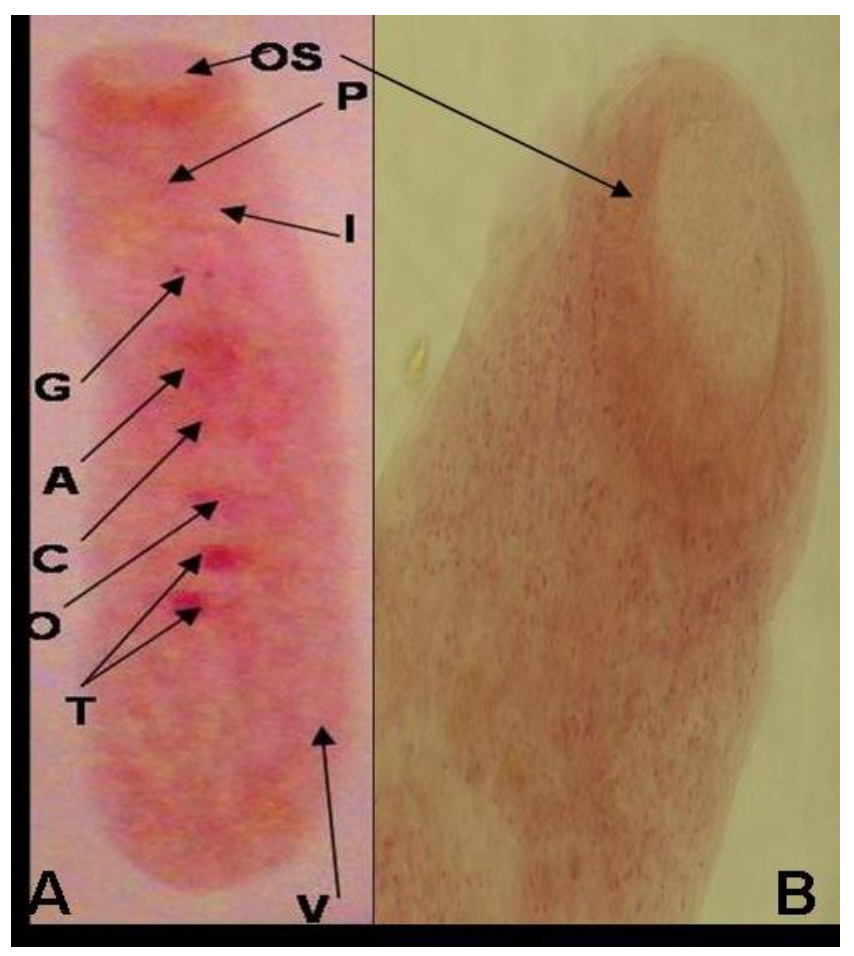

Fig. (5): Larval stage of Dolichosacculus solecarius. A) The whole worm. B) Anterior end. Os $=$ Oral sucker, $\mathrm{P}$ $=$ Pharynx, $\mathrm{I}=$ Intestinal ceca, $\mathrm{G}=$ Genetal pore, $\mathrm{A}=$ Acetabulum, $\mathrm{C}=$ Cirrus pouch, $\mathrm{O}=$ Ovary, $\mathrm{T}=$ Two testes, $\mathrm{V}=$ Vitellaria.

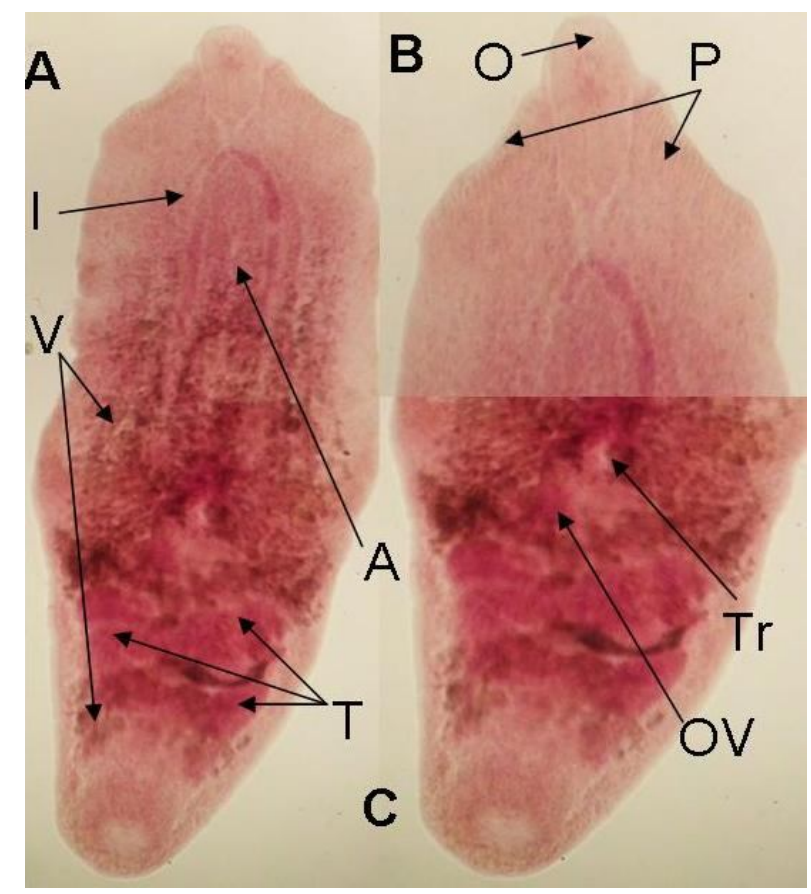

Fig. (6): Tylodelphys sp., A) The Whole worm. B) Anterior part. C) Posterior part. I: Intestinal bifurcation, V: Vetellaria, A: Acetabulum, T: Testes, O: Oral sucker, P: Pseudosuckers, Tr: Tribocytic organ, OV: ovary. 


\section{DISCUSSION}

Petasiger skrjabini was first recorded from Falco tinnunculus by Skrjabin et al. (1947) and distributed in Asia and America. The detailed morphological and metrical data obtained for P. skrjabini in the present study (Fig. 1) agree well with the description of $P$. neocomense. This species was distinguished solely on the basis of the holotype having symmetrical testes (Bashkirova, 1941). The measurements of body length, body width, oral sucker, pharynx, ventral sucker, ovary, anterior tests, and posterior tests for $P$. skarjabini are comparable to previously measurements by Faltynkova et al. (2008). It also agrees well with their description from Podiceps cristatus who consequently considers $P$. skrjabini to be a synonym of $P$. neocomense. They were found to possess oblique, rather than parallel testes. Kostadinova and skirnisson (2007) reported P. nitidus from Podiceps auritus and P. cristatus in China. A comparison of the description of these authors with our data on the type-material of Petasiger nitidus revealed that, although the Chinese material resembles $P$. nitidus in body dimensions, it exhibits much lower limits for the size of the testes and ovary .The cirrus sac in $P$. nitidus is also substantially larger both in absolute dimensions and in relation to the body width and the size of the ventral sucker. Kostadinova and Skirnisson (2007) recognized this material as conspecific with $P$. longicirratus that described from Chinese material (Ku, 1938).

Finding of Petasiger jubilarum in this study (Fig. 2) matched the previous seen descriptions of Skrjabin et al. (1947) from Falco tinnunculus, Yamaguti (1958), McDonaled (1981). Nasincova et al. (1994) suggested a possible synonymy of this form with $P$. variospinosus. Faltynkova et al. (2008) described this species from a single juvenile of Falco tinnunculus and probably macerated specimen (lacking tegumental spines).

The newly collected material of Petasiger grandivesicularis from herring gull (Fig. 3) exhibits a higher variation in the metrical features. Thus the size of body and most of the other metrical features (correlated with body size) were found to vary above the upper ranges given in the original description of P. grandivesicularis (Ishii, 1935). The material of Yamaguti (1939) exhibited somewhat greater upper limits for the size of the body, collar, ventral sucker, cirrus and anterior testis, thus extending the known range for this species. P. grandivesicularis is the only species in the genus with its vitelline fields confluent in the forebode (Faltynkova et al., 2008). Other characteristic features include: small body, large cirrus-sac, bulb-like cirrus and eggs large in relation to body size. However $P$. grandivesicularis resembles $P$. australis which described by (Faltynkova et al.,
2008) in Australia from Tachybaptus ruficollis in the structure of the vitellarium (i.e. it is composed of large follicles) and its extent in the forebody, but differs in most metrical characters and in the $\mathrm{f}$ act that the vitelline fields, although approaching the mid-line anterior to the cirrus-sac, are not confluent. Also we can be distinguished it from $P$. australis and $P$. neocomense by the larger dimensions of the body and angle spines (Faltynkova et al., 2008). Odening (1965) described P. neocomense from Podiceps cristatus in the vicinity of Berlin, which was later, redscribed and identified as Petasiger grandivesicularis (Kostadinova, 1999). Cankovic et al. (1983) and Kostadinova and Matskasi, (1994) listed two hosts, Tachybaptus ruficollis and Podiceps cristatus and this indicates that they have more than likely presented a composite description of Petasiger grandivesicularis and $P$. neocomense.

Stephanoprora spinosa trematode species of reptiles and fish was found in herring gulls during this study (Fig. 4). This species was identified according to the description of Yamaguti (1958) and McDonald (1981). Presence of this species in gulls may be due to feeding on reptiles or gulls may be considered as a new host for this trematode.

Dolichosacculus solecarius larvae in the present study (Fig. 5) are matched with the finding of Yamaguti (1958). The likely source of trematode infection in this study was fish and reptiles which considered the favorite food for herring gull at all. This explained the impact of sea birds on fish as a source of protein for human consumption. Also, this study was the first record for five species of trematode helminth parasites in aquatic birds in ElManzala Lake in Port-Said Province.

The morphology and measurements of the Tylodelphys sp. are corresponding well to that of Tylodelphys sp. as described by Moravec (2001) from the Czech of Republic. The metacercaria of the Tylodelphys sp. recorded from the eye of fishes of genus Cobitis taenia in Poland by Marcin and Kotusz (2003). Yamaguti $(1958,1971)$ and Skrjabin (1960) clearly distinguished between the genera Diplostomum, and Tylodelphys. The features of the adult parasite, namely body form, size of the tribocytic organ, size and form of the hindbody, position of ovary, size of the anterior testis and vitelline field distribution, clearly indicate this species to fall in the genus Tylodelphys. Fishes are the source of infection for the gulls as it affect on the production of the fishes which act as the main source of protein to human consumption.

Regarding the total prevalence of trematode infestation in herring gull, it was $61.54 \%$ as shown in Table 1, which was lower than that recorded by 
Kalantal et al. (2000) (98\%) in slender-billed gull collected from Al-rames coast of Al-Qateef in eastern province of Saudi Arabia. Moreover, the prevalence of each trematode species recorded in this study is differed from their findings. This might be due to the diversity of the helminthes as well as the aquatic gull.

From the point of zoonotic view, the trematodes belong to the family Echinostomatidae are considered a great public health hazards parasites causing Echinostomiasis (Synonym: Echinostomatidosis) which live in the intestine of mammals, birds and occasionally humans. The definitive host, including man, becomes infected by consuming raw foods (intermediate hosts) containing metacercariae (Pan American Health Organization, 2003). The aquatic birds herring gull may play an important role in transmitting parasites to fish which in turn transmitting them to humans. Although the isolated Echinostomatid species, in this study, are not recorded as zoonotic ones but evidence suggests some fish parasites that are currently not considered as human pathogens may become a human health concern in the future (USFDA, 2001).

\section{CONCLUSION}

As a result of present study, 6 species of digenetic trematodes belonging to 3 families were recorded from Larus argentataus from El Manzala Lake and Mediterranean Sea near Port Said city of Egypt. This study supports the view of Kennedy and Baker (1989) that in gulls as a group, helminth communities show common features of high species richness, low abundance, few or no core species and a number of species that occur rarely. Moreover, this relative species richness and diversity of the helminths are comparable to those of other gulls reported from other parts of the world and probably reflect the specialized non- selective diet of Larus argentataus.

\section{REFERENCES}

Abdel Aal, A.A.; Badawy, G.A. and Ghattas, M.W. (2001): Some digenetic trematodes of the black headed gulls (Larus ridibundus) caught from El_Manzala Lake and Mditerranean Sea at Port_Said, Egypt. J. Egypt. Vet. Med. Ass. 61 (6): $145-161$.

Abdel Aal, A.A. and El Sayed, N.M. (2003): Internal parasites of some migrant and farmed Quails in Egypt. J. Egypt. Vet. Med. Soc. Parasitol., 1, 29-47.

Bashkirova, E.Y. (1941): Bird echinostomatids in the USSR with a review of their life-cycles. Trudy
Bashkirskoi Nauchnoissledovatel'skoi Veterinarnoy Opitnoy Stantsii, 3, 243-300 (in Russian).

Cankovic, M.; Kazic, D. and Milka, R. (1983): Helmintofauna vodenih ptica iz familije Podicipidae Skadarskog jezera. Digeni trematodi. II. Familija: Echinostomatidae Dietz, 1909. Veterinaria (Sarajevo), 32, 181-193.

Eyda, M.; Gunnlaugsdottir, B. and Olafsdottir, D. (1996): Gulls (Laridae) in Iceland as final hosts for digenian trematodes. Bull. Scand. Soc. Parasitol., 120-121.

Fahmy, M.A.M. and Selim, M.k. (1959): Studies on some trematode parasites of dogs in Egypt with special reference to the role-played by fish in their transmission. Z.Parasitenkd.19, 313.

Faltynkova, A.; David I. Gibson and Kostadinova, A. (2008): A revision of Petasiger Dietz, 1909 (Digenea: Echinostomatidae) and a key to its species. Syst Parasitol (2008) 71: 1-40

Fuhrmann, O. (1927): Petasiger neocomense nov. sp. Une nouvelle espe'ce d'Echinostomides. Bulletin de la Socie'te' Neucha^teloise des Sciences Naturelles (Novelle se'rie), 1, 3-6

Ghattas, M.W. (2004): Investigation on enteric helminth parasites of some aquatic birds at Port Said Governorate. J. Egypt. Med. Assoc.64 (5): 151-175.

Grant, Peter J. (1986): Gulls: a guide to identification ISBN 0-85661-044-5.

Howell, Steve N.G. and Jon, D. (2007): Gulls of the Americas ISBN 0-618-72641-1.

Ishii, N. (1935): Studies on bird trematodes. III. Bird trematodes in Japan (continued). IV. Seven new bird trematodes. Japanese Journal of Experimental Medicine, 13, 275-284.

Kalantal, A.M.N.; Arfin, M. and Almosjen, A.A. (2000): Digenetic trematodes of Larus ganei (Lariformis: Laridae) caught from Al-rames coast of Al-Qateef in eastern provence of Saudi Arabia. Pakistan Journal of Biological sciences 3 (10): 1708- 1711.

Kennedy, C.R. and Baker, T.R. (1989): Diversity in helminth communities in common gulls, Larus canus. Parasitology, 98: 439-445.

Kostadinova, A. (1995): Trematodes of birds of the family Ardeidae from the Bulgarian black sea coast. Comptes rendus del' Academie bugare des Sci., 48: 89-91.

Kostadinova, A. (1999): First record of Petasiger grandivesicularis Ishii, 1935 (Digenea: Echinostomatidae) in Germany. Helminthologia, 36, 101-103.

Kostadinova, A. and Matskasi, I. (1994): A new geographical record of Petasiger grandivesicularis Ishii, 1935 (Digenea: 
Echinostomatidae). Parasitologia Hungarica, 27, 39-44.

Kostadinova, A. and Skirnisson, K. (2007): Petasiger islandicus n. sp. (Digenea: Echinostomatidae) in the horned grebe Podiceps auritus (L.) (Aves: Podicipedidae) from Iceland. Systematic Parasitology, 68, 217-233.

Kreiter, A. and Semenas, L. (1997): Helminth parasites of Larus dominicanus in Argintinian Patagoni. Bol. Chil. Parasitol., 52: 39-42.

$K u, C .-T$. (1938): New trematodes from Chinese birds. Peking Natural History Bulletin, 13, 129-136.

McDonald, M. (1981): Key to trematodes reported in Waterfowl. Resource publication 142 Washington, D.C. pp. 67.

Moravec, F. (2001): Checklist of the Metazoan Parasites of fishes of the Czech Republic and the Slovak Republic (1873-2000). Academia, Parha, 168 pp.

Marcin, P. and Jan, K. (2003): Endoparasitic helminthes of fishes of the genus Cobitis from Poland. Folia biologica, vol. 51: 173-177.

Nasincova, V.; Scholz, T. and Moravec, F. (1994): Redescription of Petasiger exaeretus Dietz, 1909 and P. phalacrocoracis (Yamaguti, 1939) (Trematoda: Echinostomatidae), parasite of cormorants. Systematic Parasitology, 27, 139147.

Odening, K. (1965): Zur Trematodenfauna der einheimischen Lappentaucher und des Blesshuhns. Abhandlungen und Berichte für Naturkunde und Vorgeschichte, 11, 119-132

Olsen, K. and Larsson, H. (1995): Terns of Europe and North America. Christopher Helm, London. ISBN 0-7136-4056-1.

Pan American health Organization (2003): Zonooses and communicable diseases common to man and animals. Third edition. Volum III. Parasitoses. Washington, D.C. Scientific and Technical Publication No. 580.

Roca, V.; Lafuente, M. and Carbonell, E. (1999): Helminth communities in audouin's gulls,
Larus audouinii from Chafarinas Island (Western Mediterranean). J. parasitol., 85: 984-986.

Skrjabin, K.I. (1960): Trematodes of animals and man-Essentials of trematodology, Vol. XVIII. Academy of Sciences of the USSR, Helminthological Laboratory, Moscow.

Skrjabin, K.I.; Petrov, A.M. and Bashkirova, E.Y. (1947): Echinostomes of domestic and game birds of the USSR. In K.I. Skrjabin (Ed.), Trematodes of animals and man. Osnovy Trematodologii, 1, 392-489 (in Russian).

Soulsby, T.J.L. (1986): Helminth, Arthropods and protozoa on domesticated animals $7^{\text {th }}$ ed., Bailliere Tindall, London, pp: 809.

Thu, N.D.; Dalsgaard, A.; Loan, L.T. and Murrell, K.D. (2007): Survey for zoonotic liver and intestinal trematode metacercariae in cultured and wild fish in An Giang Province, Vietnam. Korean J. Parasitol., 45 (1): 45-54.

Torres, P.; Ruez, E.; Gesche, W. and Montefusco, A. (1991): Gastrointestinal helminth of fish-eating birds from Chiloe Island, Chile. J. Wildl. Dis., 27: $1178-1179$

Uchida, A.; Uhida, K.; Itagaki, H. and Kamegai, S. (1991): Check list of helminth parasites of Japanese birds. Jpn.J. Parasitol., 40: 7-85.

United State Food and Drug Adminstration (USFDA) (2001): Processing parameters needed to control pathogens in cold smoked fish: parasites. FDA/CFSAN. Hypertext.

Williams, H. and Jones, A. (1994): Parasitic worms of fish. Taylor and Francis Ltd. U.K., pp: 593.

Yamaguti, S. (1939): Studies on the helminth fauna of Japan. Part XXV. Trematodes of birds, IV. Japanese Journal of Zoology, 8, 129-210.

Yamaguti, S. (1958): Systema helminthum. The digenetic trematodes of vertebrates- part 1 . Vol. (1). Interscience publishers, Inc., New York. Pp. 637.

Yamaguti, S. (1971): Synopsis of digenetic Trematodes of Vertebrates. Vol. 1. Keigaku. Publishing Co., Tokyo (Japan).

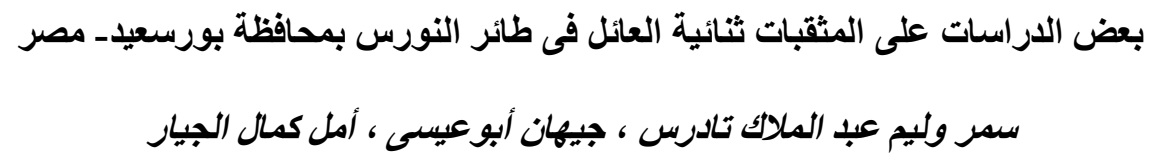

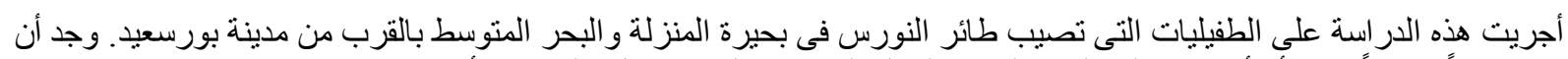

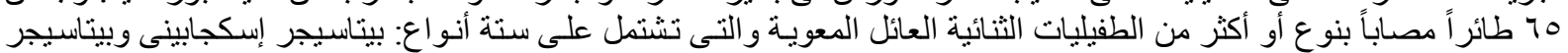

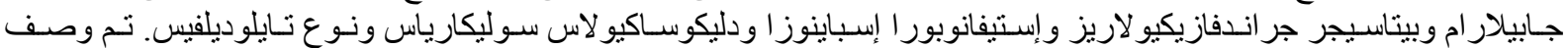

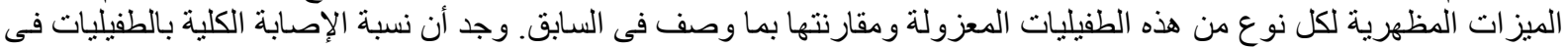

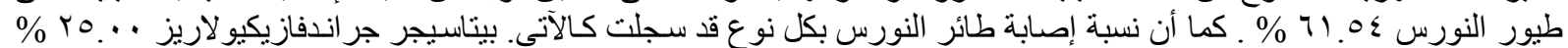

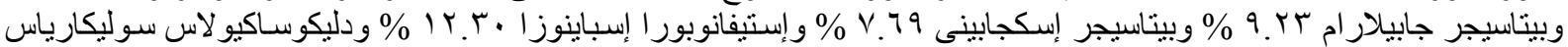

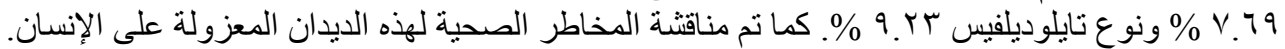

